\title{
On the Structural Weaknesses of the post-1999 Turkish Disinflation Program
}

\author{
AHMET ERTUĞRUL and ERINÇ YELDAN
}

Turkey initiated an extensive disinflation program in December 1999, which was backed and supervised by the International Monetary Fund (IMF). The aim of this program was to decrease the inflation rate to a single digit by the end of 2002. It relied exclusively on a nominally pegged (anchored) exchange rate system for disinflation, which has been a major concern for Turkish policymakers for over three decades. In November 2000 , however, one year after introducing the program, the country experienced a very severe financial crisis. More than $\$ 6$ billion of shortterm capital fled the country, creating a severe liquidity shortage and skyrocketing interest rates.

In early December 2000, the government requested access to the Supplemental Reserve Facility of the IMF. The request was granted, with $\$ 7.5$ billion of additional support provided on December 22, and the revision of the technical targets of the monetary program. Only then could continued implementation of the program be secured, as the markets seemed to have calmed down. However, on February 19, 2001, shortly after this arrangement with the IMF, the public disclosure of a political dispute between the prime minister and the president badly wounded the uneasy markets. The Central Bank was forced to sell a large portion of its foreign reserves in an attempt to support the Turkish lira (TL) as the shortterm interest rates rocketed to over 5,000 percent. In the period that followed, the government could not endure the pressures of the markets any further, and declared the surrender of the pegged exchange rate system on February 22, thereby letting the exchange rates free float.

Following the demise of the exchange rate-based disinflation program, the newly appointed Finance Minister, Kemal Derviș (former vice president of the World Bank) submitted a new letter of intent to the IMF. On May 15, Derviș announced the invigoration of a new stabilization effort under the guidance of a program entitled "Turkey's Transition Program: Strengthening the Turkish Economy." As mentioned in its introduction, the 
new program would be the continuation of the previous disinflation program and would be backed by a series of "structural reforms" aimed at strengthening the banking system and at transforming the "old ways of economic policy making." "

However, the September 11 terrorist attack undermined the implementation of this new program, affecting investors' perceptions adversely. The Turkish government requested, in turn, a new three-year, stand-by arrangement for offsetting the detrimental effects of the external shock. The IMF accepted the new letter of intent dated January 18, 2002, by providing a considerable amount of financial support.

The last two stand-by arrangements should clearly be regarded as the continuation of the disinflation program launched at the end of 1999, even though they were implemented after its failure. The main framework of the program itself, as well as the crisis episode, has been a source of debate since its very beginning. ${ }^{2}$ In particular, it was alleged by the former deputy managing director of the Fund, Stanley Fischer, that the difficulties in Turkey relate more to the banking sector and to the deterioration of macroeconomic fundamentals rather than any errors in program design. ${ }^{3}$ In particular, according to Fischer, "The recent difficulties in Turkey relate more to banking sector problems, and the failure to undertake corrective fiscal measures when the current account widened." ${ }^{4}$

This contribution will attempt to examine this assertion given the available macroeconomic evidence for Turkey. In particular, we highlight the structural weakness of the exchange rate-backed disinflation program as manifested in its liquidity creation mechanism in a small and fragile financial system such as Turkey. An analytical inquiry into the structural causes of the Turkish crisis is clearly not limited to a theoretical curiosum; such an inquiry has clear implications for stabilization policy and for the culpability of the IMF-style austerity programs. Given the painstaking financial crises of the 1990s in the developing world, such stocktaking on the theoretical underpinnings of the orthodox stabilization plans is both timely and urgent. The essay is constructed as follows: the next section points to the underlying liquidity generation mechanism of the 2000 Turkish disinflation program; the following section documents the fragility indicators of Turkish banking, and argues that the disinflation program led to increased vulnerability in the banking system throughout $2000 / 1$; we then briefly overview the fiscal fragility indicators of the public sector and study the behavior of the interest rates under the program; finally, we provide a summary and some concluding comments. 


\section{THE LIQUIDITY GENERATION MECHANISM}

UNDER THE DISINFLATION PROGRAM

The 2000 Turkish disinflation program adopted the monetary approach to balance of payments as its theoretical foundation for the determination of the liquidity generation mechanism and the resolution of the balance of payments equilibrium. This approach, which provides the underlying frame of reference for almost all IMF-style austerity programs, expects the real exchange rate to be in long-run equilibrium at its purchasing power parity level, and maintains that the domestic supply of money be "endogenized" in a regime of open capital account.

Accordingly, the program limited the monetary expansion to changes in the net foreign asset (NFA) position of the Central Bank, and fixed the Bank's stock of net domestic assets (NDA) at its December 1999 level. It was further announced that the Central Bank would be allowed to change its net domestic asset position within a band of \pm five percent of the monetary base, to be revised at three-month intervals. The implication of the rule necessitated the following identity:

\section{Monetary Base $=$ Net Foreign Assets + Net Domestic Assets}

Consequently, as a result of the restrictions set on the upper ceilings of the net domestic assets, the program limited the monetary expansion to increases in the stock of net foreign assets. ${ }^{5}$

According to this rule, the liquidity generation mechanism available to the Central Bank practically entailed a monetary regime of a semicurrency board reminiscent of its Argentine counterpart. Within this mechanism, the monetary policy is restricted to the direction of the foreign exchange flows, and, as such, the most important element - to be able to sustain the liquidity needs of the economy-would depend upon the proper continuation of the foreign credit flow into the system.

The expansion of the monetary base was ultimately linked to the foreign exchange inflows, indicating that the Central Bank was committed to the strict rule of no-sterilization throughout the program. Therefore, it was expected that the available liquidity in the domestic economy would be managed by the interest signals inherent in smoothly operating financial markets; rising domestic interest rates would invite foreign inflows, allowing for monetary expansion. Excess liquidity would, in turn, be signaled through lower rates of interest, allowing foreign capital outflows to balance the equilibrium level of liquidity in the domestic financial markets.

Figure 1 portrays the evolution of the liquidity mechanism under the first ten months of the program's implementation. The figure discloses the 
paths of the monetary base, open market operations (OMOs), the net foreign assets (NFA), and the net domestic assets (NDA) of the Central Bank, as measured by the end-of-week observations, January 7 to December 1, 2000. As can be seen, the Central Bank played the role of a currency board quite successfully until November - the first sign of the culminating crisis. Until then, the monetary base had expanded by only 7.6 percent, while the total assets of the Central Bank increased by a total of 15 percent, mostly because of the rise in foreign inflows during the summer months. All along, the Central Bank conducted its open market operations with the intent to steer the NDA within the limits of the program.

The basic message that emerges from the data in Figure 1 is clear: Turkish monetary authorities have successfully implemented the monetary program within the given targets, conditioning the Central Bank operations to net foreign inflows. In this sense, the outbreak of the November crisisand the ultimate collapse of the program in February 2001 - cannot be attributed to any divergence from the monetary targets.

However, with the eruption of the first crisis in November 2000, and then again in February 2001, it was clear that the basic foundations of the liquidity creation mechanism were at fault. In fact, given the shallowness and fragility of the Turkish financial system, the mechanism was always incapable of bringing about such smooth adjustments towards equilibrium as those envisaged by the program designers. In Table 1 we lay out the basic characteristics of the financial system.

\section{FIGURE I}

MONETARY BASE, NET DOMESTIC ASSETS, NET FOREIGN ASSETS

AND NET OPEN MARKET OPERATIONS

(JANUARY 7, 2000-DECEMBER 1, 2000, END-OF-WEEK OBSERVATIONS)

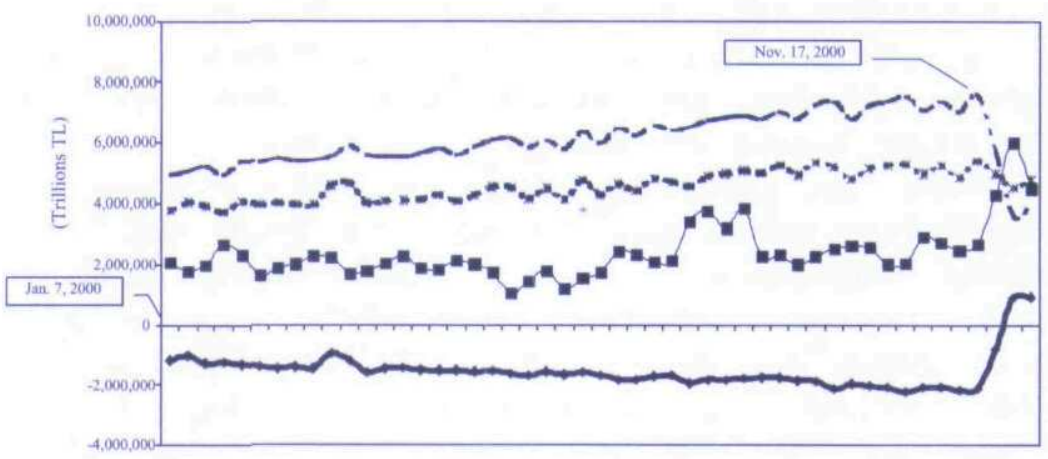

- *- Monetary base - - Net foreign assets $\quad$ Net domestic assets $\rightarrow$ Net OMOs 
TABLE 1

BASIC CHARACTERISTICS OF THE FINANCIAL SYSTEM

\begin{tabular}{|c|c|c|c|c|c|c|c|}
\hline \multirow[b]{2}{*}{$\begin{array}{l}\text { Total } \\
\text { Assets } \\
\text { of the } \\
\text { Banking } \\
\text { Sector } \\
\text { / GNP }\end{array}$} & \multicolumn{2}{|c|}{$\begin{array}{l}\text { Banking Sector } \\
\text { Foreign Credits }\end{array}$} & \multirow[b]{2}{*}{$\begin{array}{l}\text { Net } \\
\text { Short } \\
\text { Term } \\
\text { Capital } \\
\text { Flows } \\
\text { (Bill } \\
\text { US\$) }\end{array}$} & \multirow[b]{2}{*}{$\begin{array}{c}\text { Current } \\
\text { Account } \\
\text { Balance } \\
\text { / GNP }\end{array}$} & \multirow[b]{2}{*}{$\begin{array}{l}\text { Total } \\
\text { Foreign } \\
\text { Debt } \\
\text { / GNP }\end{array}$} & \multirow[b]{2}{*}{$\begin{array}{l}\text { Short } \\
\text { Term } \\
\text { Foreign } \\
\text { Debt } \\
\text { / CB } \\
\text { Reserves }\end{array}$} & \multirow[b]{2}{*}{$\begin{array}{c}\text { Currency } \\
\text { Sub- } \\
\text { stitution* }\end{array}$} \\
\hline & 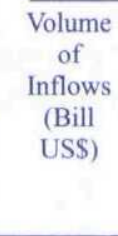 & $\begin{array}{c}\text { Volume } \\
\text { of } \\
\text { Outflows } \\
\text { (Bill } \\
\text { US\$) }\end{array}$ & & & & & \\
\hline 52.2 & 76,427 & 75,626 & 3,713 & -14 & 42.8 & 126.7 & 54.8 \\
\hline 59.4 & 8,824 & 8,055 & 5,945 & -1.3 & 46.2 & 104.2 & 50.9 \\
\hline 65.9 & 19,110 & 18,386 & 1,761 & -1.4 & 47.8 & 95.1 & 48.6 \\
\hline 69.4 & 19,288 & 19,225 & 2,601 & 1.0 & 50.9 & 105.4 & 45.1 \\
\hline 92.1 & 122,673 & 120,603 & 759 & -0.7 & 55.7 & 98.9 & 45.2 \\
\hline 82.8 & 209,432 & 204,691 & 4,035 & -4.8 & 58.3 & 127.6 & 44.1 \\
\hline
\end{tabular}

Note: * Rate of Dollarization-Ratio of foreign exchange deposits to total deposits of residents.

Sources: Central Bank Balance of Payments Statistics; State Planning Organization, Main Economic Indicators, at $\langle$ http://ekutup.dpt.gov.tr/teg/2003/02/mei.html $>$.

As indicators tabulated in Table 1 reveal, the strategy of "public sector deficit financing based on short-term foreign borrowing" led the banking system to be more vulnerable to foreign exchange and interest risks. Increasingly unhedged risk-taking behavior, coupled with a remarkable build-up of the short positions in foreign currency in the banking sector, raised serious doubts about the sustainability of the short-term capital inflow-based public debt management policies.

As manifested in Table 1, the total assets of the banking sector to the ratio of gross national product (GNP) stood at around 80 percent. On the other hand, the sheer volume of short term foreign capital flows intermediated through the banking sector is clearly indicative of their gross volatility and erratic movements. The volume of inflows of banking credits reached \$122.7 billion in 1999 and \$209.4 billion in 2000. Consequently, the ratio of short-term debt rose abruptly in 2000. Yet, the authors of the Letter of Intent had envisaged that possible increases in Central Bank reserves would be able to match the increase in outstanding short-term foreign debt, and that Turkey would be able to remain sound externally. However, during the course of the year the banking sector succeeded in increasing the net inflows of foreign credit by $\$ 4.7$ billion. During this process, total short-term debt stock of the banking sector increased to $\$ 16.9$ billion from its level of $\$ 13.2$ billion. The lure of the uncontrolled 
flows of speculative gains clearly grew unchecked throughout 2000, during which the currency risk was eliminated and the entire liquidity generation mechanism was based on the short-term hot money inflows.

As a quantitative indicator of the short-term speculative capital flows, we further report on the behavior of the residents' and non-residents' portfolio purchases and sales of securities, both domestically and abroad. Data on the residents' sales of securities (inflow of foreign exchange) and purchases of securities (outflows) is depicted in Figure 2a. Figure 2b sets out the security purchases (inflows) and sales (outflows) of non-residents. All data are monthly series in millions of dollars and are derived from the Turkish Republic Central Bank's balance of payments statistics. ${ }^{6}$

The volatility of the flows and the disruptive spikes of outflows due to non-residents' operations during November 2000 and February 2001 are clearly visible in Figure 2b. According to Boratav and Yeldan's calculations, before the November 2000 crisis non-residents brought a total of $\$ 15.2$ billion of "hot money" into the Turkish asset markets, while the residents enabled an outflow of $\$ 5.3$ billion. $^{7}$ Thus, during the course of the program, much of this accumulated short-term debt seems to have financed the flight of residents' capital.

A related indicator of structural fragility present in the system pertains to the degree of dollarization. Measured as the ratio of foreign exchange deposits to total deposits of residents, this ratio - which was as high as 55 percent in 1995 - stood at 45 percent just before the inception of the program. The ongoing currency substitution, then, had severely limited the capability of the monetary authority to control the domestic liquidity.

FIGURE 2a

PORTFOLIO INVESTMENTS: SECURITIES SALES (INFLOWS) AND PURCHASES (OUTFLOWS) BY RESIDENTS ABROAD (MILLIONS US\$)

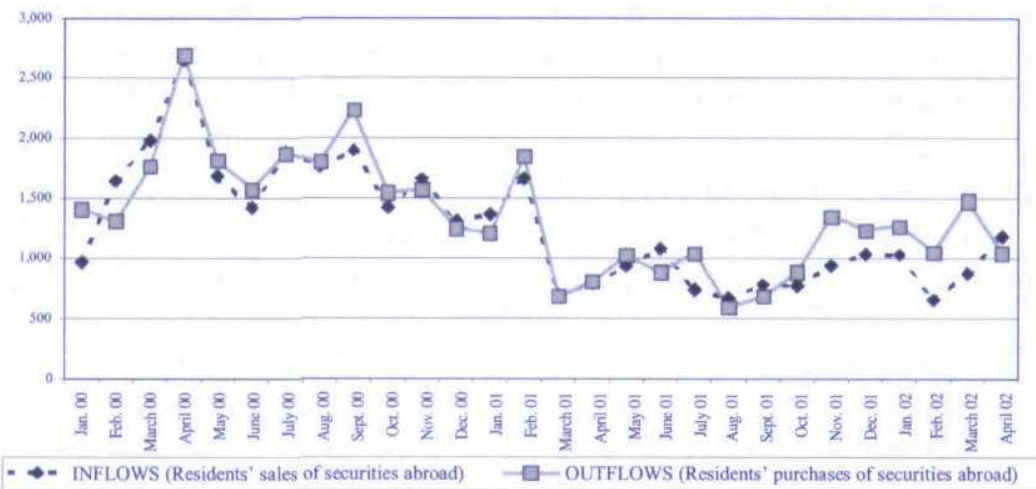




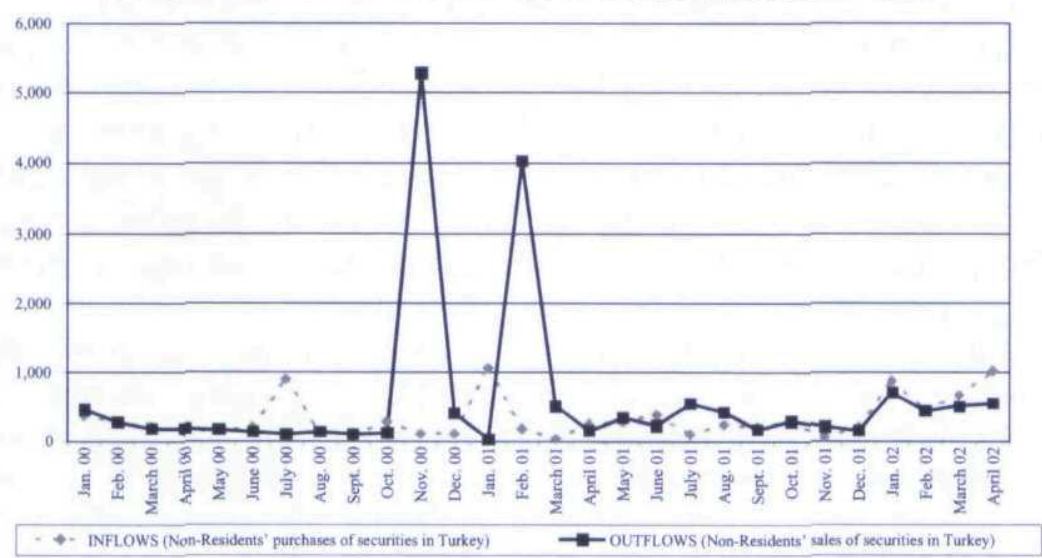

Source: Based on data from the Central Bank, available at <http://www.tcmb.gov.tr>.

Thus, ignoring these historical attributes and structural characteristics of the banking system, the orthodox policy of fully connecting the monetary expansion and liquidity requirements of the domestic economy exclusively to the speculative short-term capital flows was clearly a design flaw - an oversight by the IMF, despite their technical expertise.

\section{DEEPENING THE VULNERABILITY OF THE BANKING SYSTEM}

As argued in the preceding section, the underlying cause of the Turkish currency crisis cannot be attributed to the failure of the fiscal and/or monetary authorities in maintaining the main targets of the monetary program. Throughout the year, exchange rate devaluation followed the programmed schedule and the Central Bank successfully controlled the expansion of the monetary base by constraining its net domestic asset position within the program limits.

Similarly, the fiscal operations were in line with both the revenue and the expenditure targets, and the non-interest primary balance on the consolidated budget succeeded in attaining the end-of-year target by as early as September. Consolidated budget data tabulated from the Undersecretariat of Treasury and the Ministry of Finance reveal that budget revenue realizations were actually higher than the targeted values 
by 3.6 percent in 2000 and by 5.1 percent in 2001 . On the other hand, expenditure remained 0.2 percent lower than the 2000 target, and the 2001 targets were exceeded by only 1.7 percent. Consequently, during the years in question public management expenditure and revenue targets were achieved and the primary (budget) surplus as a ratio to national income (including privatization and other non-fiscal revenues) increased to 6.1 percent in 2000 and to 6.7 percent in 2001. This "success" in the public sector balances was attained by restricting expenditure on public services through the extraordinary forced shrinkage of public investments, and by way of extraordinary taxation possibilities particular to $2000{ }^{8}$

Clearly, the fiscal austerity objectives reached were far below the program's target. Crisis conditions emerged in due course, mainly as a result of the increasing fragility in the financial system. This fragility was generated by the uncontrolled and excessively volatile capital flows with an exceedingly speculative component. Under the liberalized capital account system, capital inflows intrinsically necessitated a higher rate of return on domestic assets in comparison to the rate of depreciation. This commitment stimulated further foreign capital inflow, and the domestic currency continued to appreciate - inviting an even higher level of speculative capital inflow. ${ }^{9}$

In the context of the Turkish disinflation episode, debt-financed public deficit and rapid acceleration of private expenditure escalated inflows of short-term foreign capital and severely increased the vulnerability of the shallow banking system. As a result, the ratio of the short-term foreign debt to the Central Bank's international reserves rose steadily throughout the program (see Table 1). This ratio is regarded as one of the crucial indicators of external fragility. It could be argued that the value of 60 percent for this ratio is considered a critical threshold from an international speculation point of view. ${ }^{10}$ It is alarming to note that in the Turkish case this particular ratio has never fallen below the 100 percent mark since the liberalization of the capital account in 1989. Thus, for the past 12 years the Turkish financial system has been operating constantly in the "danger zone," as far as this indicator is concerned. During the implementation of the disinflation program this ratio rose to 112 percent in June 2000 and to 147 percent by early December $2000 .^{"}$

Thus, the implementation of the program itself increased the financial fragility of the domestic asset market. The combined effect of an easy deficit financing policy and a liquidity-creating mechanism allowing for no-sterilization induced many commercial banks to shift their asset management policies toward bond-financing activities. The share of government debt instruments in total assets rose from 10.3 percent in 1989 (completion of capital account liberalization) to 21.3 percent in 1999 , and 
was 19.8 percent in $2000 .^{12}$ The growing willingness of banks to increase their bond-financing activities under these conditions increased the fragility of the financial sector against uncovered interest risk. In addition, the aggressive security management policy of some commercial banks raised further doubts concerning their sustainability.

It must be further noted in this context that - since the liberalization of the capital account in 1989 - the asset and liability structures of the banking system have changed substantially. The liability dollarization ratio increased from 25 percent to 48 percent by the end of 1999. In the same period, asset dollarization rose from 26 percent to 38 percent, and the share of the dollar-denominated deposits rose up to 55 percent. ${ }^{13}$

The short-term foreign capital inflow-based deficit financing policy of the government, accompanied by high real rates of interest, incited the commercial banks to extend their short positions in foreign currency, overlooking prudential asset-liability management. Figure 3 depicts the foreign versus domestic (TL) liability and asset structure of the banking system during the 1990s. The steady rise of the open position of the banking system after 1996 is clearly visible. During the implementation of the program - with the elimination of currency risk - the net short position of the banking system nearly doubled, deepening the vulnerability of the banking system against foreign currency risk. ${ }^{14}$

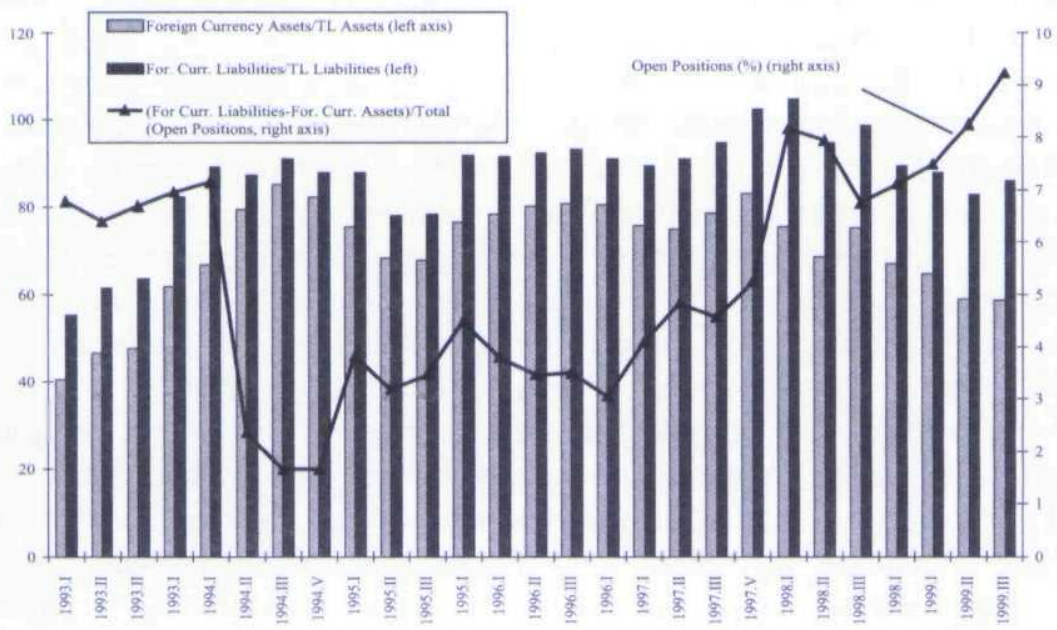


In sum, the program and its liquidity creation mechanism deepened the vulnerability of the banking system to market risks, which have been inflicted since the liberalization of capital movements.

\section{THE STRUCTURE OF FISCAL FRAGILITY \\ AND THE BEHAVIOR OF INTEREST RATES}

Given past experience of exchange rate-based stabilization programs, it is now regarded as an empirical regularity that they initially generate a demand-based expansion accompanied by rising and usually unsustainable trade and current deficits and are followed by a phase of contraction-the magnitude of which depends on the size of the earlier external deficits. During the course of implementation these programs are often associated with the build-up of a bubble in the asset markets. Yet, as the fragility of the banking system against market risks rises and doubts about the program's sustainability are intensified, capital inflows reveal a "sudden stop," heavily squeezing liquidity and sending domestic rates of interest rocketing. This sequence is well matched with the traditional transmission mechanism of exchange rate-based stabilization programs, ${ }^{15}$ and in particular the November 2000 and February 2001 crisis episodes in Turkey.

In a financially shallow economy and a fragile banking system, the first disruptive effect of sudden stop and capital reversal is observed in the interest rates. This is because the transmission of any monetary disturbance to the rest of the economy is conducted by interest rates and exchange rates. Yet, since exchange rate-based disinflation programs are explicitly designed to cut off any corrective adjustments of the exchange rates, the full effect of the monetary disturbance is bound to take place in the real interest rates.

In the Turkish context, following a causal relationship serves to summarize this mechanism: the un-sterilized changes in net foreign assets of the central bank induced changes in the monetary base; in turn, those were transmitted to the other real and nominal variables by changes in the interest rates as exchange rates were nominally anchored; under these conditions, the effects of the speculative capital movements on the interest rates would be magnified. The program overlooked this causal relationship and ignored its destructive effects in a fragile banking system.

In fact, the starting conditions of the program openly revealed the structural fragilities of the fiscal accounts and the consequent vulnerability of the financial system against interest rate shocks. The data depicted in Table 2 indicates the deteriorating fiscal stance of the economy. The program took over a financially fragile fiscal position of an 11.6 budget 
TABLE 2

FISCAL INDICATORS: TURKEY, 1995-2000

\begin{tabular}{lrrrrrr}
\hline & 1995 & 1996 & 1997 & 1998 & 1999 & 2000 \\
\hline As Ratio to the GNP (\%) & & & & & & \\
Public Sector Borrowing Regs. & 5.2 & 8.8 & 7.6 & 9.2 & 15.1 & 12.5 \\
Budget Balance & -4.0 & -8.3 & -7.6 & -7.0 & -11.6 & -10.9 \\
Non-interest Primary Budget & 3.4 & 1.7 & 0.1 & 4.7 & 2.1 & 5.4 \\
Stock of GDIs* & 14.6 & 18.5 & 20.2 & 21.9 & 29.3 & 29.1 \\
Interest Payments on: & 7.5 & 10.2 & 7.7 & 11.7 & 13.7 & 16.4 \\
Domestic Debt & 6.2 & 9.0 & 6.7 & 10.6 & 12.6 & 15.3 \\
Foreign Debt & 1.3 & 1.2 & 1.0 & 1.0 & 1.1 & 1.1 \\
Interest Payments / Total Tax & 43.9 & 59.2 & 41.7 & 61.0 & 66.4 & 63.7 \\
$\quad$ Revenues (\%) & & & & & & \\
Interest Payments on Domestic & 78.9 & 83.1 & 63.5 & 97.9 & 87.5 & 137.8 \\
$\quad$ Debt / Net New Domestic & & & & & & \\
$\quad$ Borrowing (\%) & & & & & & \\
Net New Domestic Borrowing / & 52.4 & 57.8 & 52.4 & 49.5 & 49.3 & 37.1 \\
$\quad$ Domestic Debt Stock (\%) & & & & & & \\
\hline
\end{tabular}

Note: Government Debt Instruments (Government Bonds + Treasury Bills), exclusive of Central Bank Advances and Consolidated Debts.

Sources: SPO, Main Economic Indicators; Undersecreteriat of Treasury, Main Economic Indicators, passim.

deficit/GNP ratio, with interest costs on domestic debt reaching 13.7 percent of the GNP. In addition to the fiscal deterioration, accrued duty losses (quasi-fiscal deficits) of the public banks reached 12 percent of the GNP (more than 50 percent of their total assets) in 2000. These accrued, but unpaid duty losses created very heavy pressure on the liquidity requirement and increased the distorting effect on the rate of interest.

Critical indicators on domestic debt management underscored the sensitivity of fiscal balances to the interest rates: interest payments on domestic debt claimed a rising portion of tax revenues of the consolidated budget in the 1990s. In 1999, this ratio stood at 66.4 percent of the tax revenues. Similarly, the fact that the net new domestic borrowing constituted half of the existing stock of domestic debt in the 1990s clearly revealed the Ponzi-character of unsustainable debt management. Interest payments on domestic debt - as a ratio of net new domestic borrowing stood at 87.5 percent in 1999 and reached 137.8 percent in 2000 after the implementation of the program.

Given these structural conditions, the program should have envisaged the destructive effects of a possible liquidity squeeze on the interest rates and on the fiscal balance. Under conditions of such interest risk with a pacified central bank, having all macro adjustment mechanisms tied to the 
interest rates constituted a clear theoretical oversight. The Central Bank was deprived of all of its traditional tools of austerity and crisis management and was left defenseless against possible "speculative attacks" and sudden stops. Under these conditions, it is no surprise that the viability of the program would finally suffer when the "uneasy speculators" shifted focus and decided to reverse their flows, leaving the incipient country illiquid and dried out.

\section{CONCLUSIONS}

The Turkish crisis, which came in the aftermath of an exchange rate-based disinflation attempt, followed all the well-documented empirical regularities of such programs: a demand-based expansion accompanied by rising and usually unsustainable trade and current deficits followed by a phase of contraction - in the form of a liquidity squeeze, skyrocketing interest rates, and negative growth. The main weakness of the 2000 disinflation program was its exclusive reliance on speculative short-term capital inflows as the source of the liquidity generation mechanism. Overlooking the existing structural indicators of financial fragility and resting the liquidity generation mechanism on speculative in- and outflows of short-term foreign capital, the program left the economy defenseless against speculative runs and a sudden stop.

The failure of the program cannot be completely tied to the inability of the government to undertake accurate actions. By deepening the vulnerability of an already shallow and fragile financial system, the underlying liquidity generation mechanism raised doubts concerning sustainability of the program itself.

In sum, muddled with the short-sighted and speculative herd behavior of domestic and foreign financial arbiters, the IMF-directed Turkish disinflation episode spells out all too clearly the dangers of restricting the monetary policy of an economy to speculative in- and out-flows of shortterm foreign capital, which, by itself, is excessively liquid, excessively volatile, and its movement subject to herd psychology. 


\section{NOTES}

1. Başbakanlık Hazine Müsteşarlığı [Undersecretariat of Treasury], TSEP Document (2000), p.1.

2. The underlying elements of the disinflation program and the succeeding crises are discussed in detail in Erinç Yeldan, "On the IMF-Directed Disinflation Program in Turkey: A Program for Stabilization and Austerity or a Recipe for Impoverishment and Financial Chaos?," in Nese Balkan (ed.), The Ravages of Neo-Liberalism: Economy, Society and Gender in Turkey (New York: Nova Science Club, 2002), pp.1-28; Korkut Boratav and Erinç Yeldan, "Turkey, 1980-2000: Financial Liberalization, Macroeconomic (In)-Stability, and Patterns of Distribution," mimeograph, CEPA and The New School for Social Research (2002) at $<$ http://www.bilkent.edu.tr/ yeldane/crisis.htm>; Ahmet Ertuğrul and Faruk Selçuk, "A Brief Account of the Turkish Economy, 1980-2000," Russian and East European Finance and Trade, Vol.10, No.37 (2001), pp.6-28; Barry Eichengreen, "Crisis Prevention and Management: Any New Lessons from Argentina and Turkey?," mimeograph, background paper for the World Bank's Global Development and Finance (2001); Ramazan Gençay and Faruk Selçuk, "Overnight Borrowing, Interest Rates and Extreme Value Theory," Bilkent University, Department of Economics Discussion Paper Nos.1-3 (March 2001); Emre Alper, "The Turkish Liquidiy Crisis of 2000: What Went Wrong?," Russian and East European Finance and Trade, Vol.10, No.37 (2001), pp.51-71; Erinç Yeldan, Küresellesme Sürecinde Türkiye Ekonomisi: Bölüşüm, Birikim, Büyüme [Turkish Economy in the Process of Globalization: Distribution, Accumulation and Growth] (Istanbul: Illetişim Publications, 2001).

3. Stanley Fischer, "Exchange Rate Regimes: Is the Bipolar View Correct?," International Monetary Fund, January, 2001, available at $\langle\mathrm{http}: / / \mathrm{www}$.IMF.org $>$. A revised version of the paper later appeared as "Distinguished Lecture on Economics in Government," Journal of Economic Perspectives, Vol.15, No.2 (Spring 2001), pp.3-24.

4. Stanley Fischer, "Distinguished Lecture on Economics in Government," Journal of Economic Perspectives, Vol.15, No.2 (Spring 2001), p.11 (emphasis added).

5. Yet, it is clear that from the point of view of the Central Bank's analytical balance sheet that expansion of the monetary base would only be possible through increased foreign earnings that would not call for an increase in the foreign liabilities of the Bank. This means that the Central Bank would not be able to increase the stock of money supply by, for example, borrowing foreign exchange from the banking system or by using the IMF's credit facility. Thus, the Central Bank would be able to issue Turkish lira and expand its monetary base only by purchasing foreign currency from the banking sector in a manner where its foreign liabilities would not be increased.

6. See <http://www.temb.gov.tr>.

7. Boratav and Yeldan (2002), p.8.

8. For further discussion on the fiscal stance of the Turkish public sector in 2000, see Yeldan (2002).

9. Elements of this vicious cycle are well known and studied extensively in the relevant literature. See, for example, Carlos F. Diaz-Alejandro, "Good-Bye Financial Repression, Hello Financial Crash," Journal of Development Economics, Vol.19, Nos.1-2 (Oct. 1985), pp.1-24; Andrés Velasco, "Financial Crises and Balance of Payments Crises: A Southern Cone Experience," Journal of Development Economics, Vol.27, Nos.1-2 (Oct. 1987), pp.263-83; Rudiger Dornbsuch, Ilan Godfajn and Rodrigo Valdés, "Currency Crises and Collapses," Brookings Papers on Economic Activity, Vol.2, No.2 (June 1995), pp.219-70; Guillermo Calvo and Carlos A. Végh, "Inflation Stabilization and BOP Crises in Developing Countries," in J. Taylor and M. Woodford (eds.), Handbook of Macroeconomics (Amsterdam: North Holland, 1999), pp.1531-614; Irma Adelman and Erinç Yeldan, "The Minimal Conditions for a Financial Crisis: A Multiregional Intertemporal CGE Model of the Asian Crisis," World Development, Vol.28, No.6 (June 2000), pp.1087-100; Kari Polanyi Lewitt, "Reclaiming the Right to Development," Paper presented at the UNRISD Conference on the Need to Rethink Development Economics, Cape Town, Sept. 2001.

10. Graciela Kaminsky, Saùl Lizondo and Carmen Reinhart, "Leading Indicators of Currency Crises," IMF Working Papers, No.97/79 (1997). 
11. Türkiye Cumhuriyet Merkez Bankası [Central Bank of Turkey], Ödemeler Dengesi Istatistikleri [Balance of Payments Statistics, 2000-2001]. See <http://www.tcmb.gov.tr>.

12. Ibid.

13. Ibid.

14. Eichengreen (2001), p.6.

15. An overview of such exchange rate-based disinflation and stabilization is summarized in Guillermo Calvo, "The Economics of Sudden Stop," mimeograph, University of Maryland (2001); Calvo and Végh (1999), p.1433; Edward J. Amadeo, "The Knife-Edge of ExchangeRate-Based Stabilization: Impact on Growth, Employment and Wages," UNCTAD Review, Vol.1, No.1 (1996), pp.1-26; Pierre-Richard Agenor, The Economics of Adjustment and Growth (London: Academic Press, 2000); Yılmaz Akyüz and Anthony Cornford, "Capital Flows to Developing Countries and the Reform of the International Financial System," UNCTAD Discussion Paper, No.143, Geneva (1999); Guillermo Calvo, Leonardo Leiderman, and Carmen M. Reinhart, "Inflows of Capital to Developing Countries in the 1990s," Journal of Economic Perspectives, Vol.10, No.1 (1996), pp.123-39; Diaz-Alejandro (1985), pp.1-24; Graciela Kaminsky and Carmen Reinhart, "The Twin Crises: The Causes of Banking and Balance-of-Payments Problems," American Economic Review, Vol.89, No.3 (June 1999), pp.473-500; Roberto Frenkel, "Capital Market Liberalization and Economic Performance in Latin America," Center for Policy Analysis, New School for Social Research, Working Paper Series III, No.1 (May 1998); Agenor and Peter Montiel, Development Macroeconomics (Princeton, NJ: Princeton University Press, 1999), Ch.8. For individual country experiences see also Vittorio Corbo, "Reforms and Macroeconomic Adjustments in Chile During 1974-84," World Development, Vol.13, No.6 (1985), pp.893-916; S. Edwards and A. Cox Edwards, Monetarism and Liberalization: The Chilean Experiment (Chicago, IL: Chicago University Press, 1991); Rudiger Dornbusch and Alexander Werner, "Mexico: Stabilization, Reform, and No Growth," Brookings Papers on Economic Activity, No.1 (March 1994), pp.253-315; Don Patinkin, "Israel's Stabilization Program of 1985, Or Simple Truths of Monetary Theory," Journal of Economic Perspectives, Vol.7, No.2 (Spring 1993), pp.103-28; Michael Bruno, Crisis, Stabilization and Economic Reform: Therapy by Consensus (London: Oxford University Press, 1993); Jose M. Fanelli, Guillermo Rozenwurcel, and Lucia M. Simpson "Argentina," in Rohinton Medhora and Jose M. Fanelli (eds.), Financial Liberalization in Developing Countries (London: Macmillan, 1998), pp.31-56; Eichengreen (2001) on Argentina and Turkey. 
Copyright of Turkish Studies is the property of Frank Cass \& Company Ltd. and its content may not be copied or emailed to multiple sites or posted to a listserv without the copyright holder's express written permission. However, users may print, download, or email articles for individual use. 